\title{
Struktura, zmiany organizacyjne i poziom nauczania Publicznej Szkoły Powszechnej w Brdowie w latach 1919-1939
}

\begin{abstract}
Structure, organisational changes and level of education at the General Public School in Brdów from 1919 to 1939.

The school in Brdów dates back to the mid-15th century. It was founded and managed by Pauline fathers. In the following centuries, the school functioned with varying degrees of success. The real development of the Brdów school occurred in the interwar period. In the following years, the structure of the school changed, due to the growing number of students. Before the outbreak of World War II, there was a general public school of 3rd level, i.e. one with seven grades, in Brdów. The teachers worked under very difficult conditions. The school building was too small to accommodate all the classes. The classrooms were overcrowded. However, the educators tried to achieve the best results possible. This was confirmed by subsequent inspections conducted by educational authorities. Just before the outbreak of World War II, a new school building was opened in Brdów which greatly improved working and learning conditions there.
\end{abstract}

Keywords: interwar period, school reorganisation, education system, education reform, interwar school, Brdów, teachers, level of education, attendance, working conditions, school in Brdów, teaching results, taught subjects, organisation, school structure, Pauline fathers.

Pierwsza historyczna wzmianka o Brdowie (gmina Babiak, woj. wielkopolskie) pochodzi z tzw. złotej bulli papieża Innocentego II (pontyfikat w latach 1130-1143) skierowanej do arcybiskupa gnieźnieńskiego Jakuba z 7 lipca 1136 r. ${ }^{1}$ Dotyczy ona granic klasztoru w Łęczycy. Wśród 410 wymienionych w niej nazw osobowych i miejscowych, pojawia się nazwa „Brdouo”2. Druga wzmianka pochodzi z 1266 r. z dokumentu, w którym wymieniono imię Alberta (Wojciecha) z Brdowa, kapelana dworu Kazimierza księ-

\footnotetext{
1 Kodeks Dyplomatyczny Wielkopolski, t. 1. Poznań 1877, dok. nr 7, s. 12.

2 J. Rozwadowski, Bulla z roku 1136 jako najstarszy zabytek języka polskiego, Kraków 1909, s. 14.
} 
cia Łęczyckiego ${ }^{3}$. Najstarsza pisana informacja o kościele pw. św. Wojciecha BM pochodzi z 1399 r. i związana jest z rozprawą sądową o wytyczenie granic dóbr kościelnych ${ }^{4}$.

Początki szkolnictwa w Brdowie wiążą się z przybyciem do tej miejscowości braci z Zakonu Świętego Pawła Pierwszego Pustelnika (OSPPE ${ }^{5}$ ) zwanych potocznie paulinami. Na mocy aktu fundacyjnego wystawionego w Krakowie 16 czerwca 1436 r. król Władysław III Warneńczyk, wykonując wolę ojca króla Władysława Jagiełły, zlecił umieszczenie ojców z zakonu paulinów w Brdowie przy istniejącym już kościele ${ }^{6}$. Fundacja ta została zatwierdzona w 1437 r. przez Władysława Oporowskiego, ówczesnego biskupa włocławskiego ${ }^{7}$. Nie jest znana dokładna data założenia przez paulinów pierwszej szkoły w Brdowie. Najstarsza źródłowa wzmianka o istnieniu szkoły parafialnej pojawia się około $1450 \mathrm{r}^{8}$, a więc w czternaście lat po przybyciu zakonników do Brdowa. Wiąże się ona z Pawłem, który występuje jako rektor szkoły w Brdowie ${ }^{9}$. Nie zachowały się źródłowe informacje o funkcjonowaniu szkoły w tym okresie. Nie wiadomo, co działo się ze szkołą w następnych dziesięcioleciach. Późniejsze źródła zdają się potwierdzać tezę, że szkoła prowadzona przez paulinów jednak działała. Sto lat później paulini otrzymali plac przy klasztorze na budowę nowego budynku szkoły, który został wybudowany. Funkcjonował on do połowy XVIII w..$^{10}$

Utrzymanie i rozwój szkoły leżały w gestii brdowskiego konwentu paulinów. Z uwag sporządzanych przez wizytatorów diecezjalnych i zakonnych można dowiedzieć się, że przeor brdowskiego konwentu opłacał rektora szkoły. Jozafat Mozga zauważył: Dom brdowski byt bodajże jednym z nielicznych konwentów zakonu, w którym przetrwaty tradycje naukowe, łaczone wespót z niewypracowanym jeszcze i na poły seminaryjnym trybem edukacji przyszłych paulinów. [...] przeor opłacał rektora szkoły, upraszajac władze diecezjalna, by pomogła $w$ zdobyciu stałego funduszu na wydatki zwiąane z edukacja ${ }^{11}$.

W 1598 r. obok rektora w szkole pracował także kantor. Wspólnie opiekowali się oni 10 lub więcej uczniami ${ }^{12}$. Szkoła w Brdowie, do której mogli uczęszczać jedynie chłopcy, posiadała odrębny budżet i statut. Pierwszymi jej rektorami bywali paulini. Program nauczania obejmował podstawy gramatyki, naukę pisania, znajomość katechizmu w języku polskim i umiejętność śpiewu ${ }^{13}$.

3 J. Zbudniewek, Dzieje osady brdowskiej, „Roczniki Teologiczno-Kanoniczne” 1984, T. XXXI, z. 4, S. 158 .

4 J. Mozga, Dzieje Konwentu Paulinów w Brdowie, „Studia Claromontana” 1984, T. 5, s. 396.

5 Ordo Sancti Pauli Primi Eremitae - Zakon Świętego Pawła Pierwszego Pustelnika.

6 J. Zbudniewek, Paulini wczoraj i dzisiaj, „Studia Claromontana” 2007, nr 25, s. 196.

7 J. Wiesiołowski, Fundacje paulińskie XIV i XV wieku nas tle ruchu fundacyjnego klasztorów w Polsce, „Studia Claromontana” 1985, nr 6, s. 151.

8 J. Mozga, op. cit., s. 437.

9 Ibidem, s. 437.

10 J.S. Mujta, Gmina Babiak przeszłość i teraźniejszość, Babiak 1995, s. 97.

11 J. Mozga, op. cit., s. 437. Por. Monumenta Historica Dioeceseos Wladislaviensis 1903, T. 22, s. 125.

12 Ibidem, s. 437.

13 Ibidem, s. 438. 
W 2 poł. XVII w. do brdowskiej szkoły zaczęli wkraczać świeccy nauczyciele. Wynikało to stąd, że powierzanie innych funkcji paulinom, odrywało ich od obowiązków kościelnych. Poziom znajomości zagadnień religijnych przez osoby świeckie był wystarczający, aby mogły one obejmować funkcje rektorów szkoły w Brdowie. W 1669 r. pełnił ją m.in. Jacek Piotrowicz, który cieszył się opinią dobrego pedagoga ${ }^{14}$.

Brdowska szkoła wykształciła przynajmniej kilku uczniów, którzy potem studiowali w Akademii Krakowskiej. Należał do nich Wawrzyniec, syn Jana z Trzebuchowa, który zapisał się na Akademię Krakowską w 1530 r. Drugi uczeń to 20-letni Józef Świderski, który immatrykulował się w Akademii Krakowskiej w 1784 r. ${ }^{15}$ Studiował na wydziale medycznym. Dokumenty krakowskiej uczelni poświadczają, że Świderski studiował przez pięć lat do 1789 lub $1790 \mathrm{r}^{16}$

W roku 1748 pożar zniszczył budynek szkolny, więc nauka na jakiś czas została zawieszona $^{17}$. Zgodnie z „Dekretem Asesorskim”, wydanym w Warszawie dnia 10 listopada 1782 r. tutejszy Klasztor Księży Paulinów obowiązany był:

1. Wybudować dom szkolny z obórka i wozownia, czyli schowaniem do drzewa.

2. Tenże klasztor powinien być nauczyciela dla dzieci utrzymywać.

3. Lokal, w którym się dzieci uczyły drzewem z borów do tutejszego klasztoru należacych zaprzegiem klasztornym sprowadzony byt i ogrzewany ${ }^{18}$.

Paulini poważnie potraktowali zalecenia i wybudowali nowy drewniany budynek szkoły, który spłonął w 1796 r. ${ }^{19} \mathrm{~W}$ następnych latach postawiono kolejny, prawdopodobnie już murowany, z przeznaczeniem na szkołę.

Odebranie konwentowi brdowskiemu folwarku w Psarach i późniejsza kasata paulinów pozbawiła szkołę jej historycznego opiekuna. Przyznać trzeba, że paulini dbali o szkołę i jej poziom nauczania, który był zapewne dość wysoki. Poziom szkoły zadecydował, że do brdowskiej szkoły uczęszczały dzieci hrabiego Jana Skarbka oraz Wodzickiego $^{20}$ z Bogusławic. Dzieci uczyły się, prawdopodobnie we wszystkich klasach, następujących przedmiotów: nauka chrześcijańska i moralność, język polski, kaligrafia, język niemiecki, język łaciński, arytmetyka. Dodatkowo w klasie trzeciej uczono geografii i historii narodu polskiego ${ }^{21}$. Poza edukacją podstawową o. Meress i o. Pouthieur uczyli dzieci także języka francuskiego i włoskiego ${ }^{22}$.

Po kasacie klasztoru paulinów w Brdowie 17 kwietnia 1819 r. ${ }^{23}$ szkoła musiała liczyć na pomoc władz miejskich. Sytuacja materialna mieszkańców miasta Brdowa była raczej

\footnotetext{
14 Ibidem, s. 438.

15 J. Mozga, op. cit., s. 438-439.

16 Ibidem, s. 439.

17 Ibidem, s. 440.

18 J.S. Mujta, op.cit., s. 99.

19 J. Mozga, op. cit., s. 440.

${ }^{20}$ Ibidem, s. 440.

21 J.S. Mujta, op. cit., s. 99.

22 J. Mozga, op. cit., s. 440-441.

23 J. Zbudniewek, Paulini wczoraj..., s. 197.
} 
trudna, tak więc szkoła nie mogła otrzymać wsparcia z ich strony. Przykładem mogą być mieszkańcy Polonisza, włościanie Michał Tomczak i Bartłomiej Szałaziński, którzy w 1824 r. stwierdzili, że: nie mogli dla krytycznych czasów deklarować składki szkolnej24. Trudna sytuacja materialna spowodowała kilkakrotne odłożenie planów związanych z budową nowego budynku szkoły. Takie plany istniały już w 1820 r. Planowano wybudować: dom szkolny, z drzewa w wagieł rżniętego na podmurowaniu, z dachem gontem pokrytym ${ }^{25}$.

Wyposażenie Szkoły Elementarnej Katolickiej w mieście Brdowie, według stanu z 1824 i 1830 r., nie wyglądało imponująco. Zachowany spis inwentarza obejmował: Jeden stół wielki do pisania, 2 stoły mniejsze, 8 tawek do siedzenia bez poręczy, 4 ławki z poręczami, 2 tablice wielkie na postumentach do rachunków, tablica mała ${ }^{26}$.

Według tego samego spisu biblioteka nauczyciela uczącego w brdowskiej szkole zawierała następujące książki: Książka dla włościan, Przepisy dla nauczyciela, Zbiór nauki chrześcijańskiej i obyczajowej, a dla uczniów: 4 sztuki tablic Lancastera do poczatkowych nauk ${ }^{27}$.

Do pomysłu budowy nowego budynku szkoły powrócono ponownie w roku 1828 . Przygotowano już nawet plan architektoniczny budynku. Aby obniżyć koszty budowy, planowano, że część prac budowlanych zostanie wykonanych bezpłatnie. Nie udało się jednak zrealizować tych projektów. Na przeszkodzie stanął wybuch powstania listopadowego i popowstaniowe carskie represje, które spadły także na mieszkańców Brdowa. W 1837 r. burmistrz Kaszewski wystosował do zwierzchnich władz pismo z prośbą o stałą dotację do kasy szkolnej, a także na fundusz potrzebny do remontu lub budowy nowego budynku szkolnego ${ }^{28}$. W 1840 r. stary budynek szkoły został wreszcie wyremontowany, ale w kolejnych latach jego stan uległ destrukcji.

Obszar parafii pokrywał się z rejonem działania brdowskiej szkoły. Rozpiętość wiekowa uczniów wynosiła od 4 do 13 lat ${ }^{29}$. W tym czasie nie istniał żaden obowiązek szkolny. Rodzice nie mieli obowiązku posyłania swych pociech do szkoły. Dość ciekawie wygląda więc statystyka związana z uczęszczaniem dzieci do szkoły w stosunku do liczby dzieci w wielu szkolnym. Jak policzył Józef Mujta: O ile w $1818 r$ r w rejonie szkoty brdowskiej ,dzieci zdatnych do szkoty” byto 194, to pobierało nauke tylko 67 uczniów (34,5\%); w 1837 r. spośród 202 dzieci w wieku szkolnym, do szkoły uczęszczało $81(40 \%)^{30}$.

Ten sam autor podzielił dzieci uczęszczające do szkoły według płci. Interesujące okazały się liczby: W 1818 r. spośród 44 uczniów, chłopcy stanowili 72,7\%, a dziewczęta

24 J.S. Mujta, op. cit., s. 97.

25 Ibidem, s. 98.

${ }^{26}$ Ibidem, s. 200; por. AGAD KWK, sygn. 2728. Inwentarz Szkoły Elementarnej w m. Brdowie w stanu z 1824 r. i 1830 r.

27 Ibidem, s. 200.

28 J.S. Mujta, op. cit., s. 98.

29 Ibidem, s. 99.

30 Ibidem, s. 99. 
27,3\%; w 1837 r. układ procentowy ulegt zmianie na korzyść dziewcząt i wynióst - 65,4\% chłopcy $i 34,6 \%$ dziewczęta ${ }^{31}$.

W roku 1901 stary, i wymagający remontu, budynek szkoły spłonął. Wybudowano nowy na fundamentach pozostałych po starej szkole ${ }^{32}$. Budynek wzniesiony został przy wsparciu finansowym brdowskiej parafii, staraniem ks. Gniazdowskiego. Poświęcenie nowo wybudowanej szkoły miało miejsce 4 listopada 1907 r. ${ }^{33}$ Izby lekcyjne wyposażono w 12 ławek, stolik, fotel, tablicę i wieszaki. Szkołą opiekowała się „Macierz Szkolna”. Mogli do niej uczęszczać zarówno chłopcy, jak i dziewczęta.

Odzyskanie przez Polskę niepodległości w 1918 r. spowodowało zmiany i rozwój szkoły w Brdowie. Dotychczas funkcjonująca, we własnym budynku, szkoła jednoklasowa mieszana zaczęła zmieniać swoją strukturę ${ }^{34}$. Kolejne jej przekształcenia były powodowane potrzebami oraz zmieniającymi się przepisami dotyczącymi organizacji publicznych szkół powszechnych w II Rzeczypospolitej.

Dekret o obowiązku szkolnym z 1919 r. zakładał, że szkoły powszechne będą tworzone w taki sposób, żeby mogły z nich korzystać wszystkie dzieci w wieku szkolnym ${ }^{35}$. Nakładał też na gminę obowiązek założenia szkoły powszechnej w każdej miejscowości, w której: liczba dzieci $w$ wieku od lat 7 do 14 włacznie wynosi w ciagu po sobie następujacych 3 lat co najmniej $40^{36}$.

Dekret obowiązywał na tym obszarze Polski, który wcześniej był częścią zaboru rosyjskiego $^{37}$. Objął więc także Brdów, który znajdował pod jurysdykcją rosyjskich władz zaborczych. Akt prawny usankcjonował wcześniejsze istnienie szkoły jednoklasowej w Brdowie. Wskazuje na to pośrednio spis zatrudnionych w niej nauczycieli. W latach 1915-1919 w brdowskiej szkole pracowała Antonina Dyakowska, a po niej objął posadę nauczyciela Jan Galewski ${ }^{38}$.

Ustawa o zakładaniu i utrzymaniu publicznych szkół powszechnych z 1922 r. ${ }^{39}$ określiła stopnie organizacyjne szkół od jednoklasowej do siedmioklasowej w zależności od liczny dzieci w obwodzie ${ }^{40}$. Ze względu na liczbę dzieci z dniem 1 września 1924 r.

31 Ibidem, s. 99.

32 Archiwum Szkoły Podstawowej w Brdowie [dalej ASPB], Kronika szkolna, s. 1.

33 J. Mozga, op. cit., s. 441.

${ }^{34}$ Archiwum Państwowe w Poznaniu. Oddział w Koninie. Inspektorat Szkolny w Kole. Szkoła Powszechna w Brdowie: organizacja, historia, akta obrazujące działalność 1924-1939 [dalej APP OK, ISK, SPB], sygn. 158, Szkoła w Brdowie. Organizacja.

35 Dekret o obowiązku szkolnym z dnia 7 lutego 1919 roku, Dziennik Prawny, nr 14, poz. 147, art. 2. s. 192, [dostęp 11.01.2015] http://isap.sejm.gov.pl/DetailsServlet?id=WDU19190140147.

36 Ibidem, art. 3., s. 192.

37 Ibidem, art. 48., s. 197.

38 APP OK, ISK, SPB, sygn. 158, Siły nauczycielskie.

39 Ustawa z dnia 17 lutego 1922 roku o zakładaniu i utrzymywaniu publicznych szkół powszechnych, Dziennik Ustaw 1922, nr 18, poz. 143, s. 284-285.

${ }^{40}$ Art. 6. Stopień organizacyjny szkoły zależy od liczby zamieszkałych w obwodzie dzieci w wieku szkolnym. Jeśli liczba ta w przeciągu 3 następujących po sobie lat nie przekracza liczby 60 - szkoła jest jednoklasowa (o jednym nauczycielu), przy liczbie od 61 do 100 - szkoła jest dwuklasowa (o dwóch nauczycielach), 
jednoklasową szkołę w Brdowie przemianowano na dwuklasową szkołę powszechną ${ }^{41}$. Z zachowanego planu lekcyjnego na rok szkolny 1924/1925 wynika, że w szkole istniały dwie równoległe pierwsze i dwie równoległe drugie klasy ${ }^{42}$. Funkcjonowanie dwóch klas wymusiło zatrudnienie jeszcze jednego nauczyciela. Obok Jana Galewskiego, który pełnił obowiązki kierownika szkoły, a później został mianowany kierownikiem, zatrudniono Tymoteusza Sosia. W następnym roku szkolnym 1925/1926 jego miejsce zajęła Maria Płonka ${ }^{43}$. Jan Galewski był wychowawcą uczniów klas drugich, a Maria Płonka opiekowała się uczniami pierwszych klas. Ksiądz Leon Jarosiński, proboszcz brdowskiej parafii, uczył dzieci religii ${ }^{44}$. Kuratorium Okręgu Szkolnego Łódzkiego w dniu 3 lutego 1927 r. zatwierdziło strukturę szkoły w Brdowie jako dwuklasową szkołę powszechną ${ }^{45}$. Liczba uczniów w szkole rosła, więc z dniem pierwszego 11927 roku zatrudniono w brdowskiej szkole kolejnych nauczycieli: Antoniego Kaźmierczaka (pracował tylko przez jeden rok szkolny) i Cecylię Urbańską, a od pierwszego października tego samego roku Władysława Kędziorę ${ }^{46}$. Decyzją Kuratorium Okręgu Szkolnego Łódzkiego z 13 sierpnia 1928 r. zmieniono strukturę placówki na czteroklasową szkołę powszechną. Rozpoczęła ona swą działalność od 1 września 1928 r. ${ }^{47} \mathrm{Z}$ tej racji 1 sierpnia 1928 r. przyjęto do pracy Marię Niezgodównę-Petrykowską ${ }^{48}$.

Kolejną zmianę organizacyjną szkoły spowodowała wzrastająca wciąż liczba uczniów uczęszczających do brdowskiej placówki. Od 1 września 1929 r. realizowano w niej program szkoły sześcioklasowej, mimo że Kuratorium Okręgu Szkolnego Łódzkiego oficjalnie zmieniło strukturę szkoły i podniosło ją do sześcioklasowej szkoły powszechnej z dniem 1 września 1931 r. ${ }^{49}$ Jak wynika z zachowanych dokumentów, w roku szkolnym 1929/1930, do szkoły w Brdowie zapisano 320 uczniów, a uczęszczało 316 $6^{50}$. Pochodzili oni z następujących miejscowości: Brdów, Kolonia od Babiaka, Kolonia od Izbicy (obecna ulica Władysława Jagiełły), Bugaj, Nowiny, Psary, Świętosławice, Gaj Stolarski.

przy liczbie od 101 do 150 szkoła jest trzyklasowa ( o trzech nauczycielach), od 151 do 200 - czteroklasowa (o 4 nauczycielach), od 201 do 250 - pięcioklasowa (o 5 nauczycielach), od 251 do 300 - sześcioklasowa (o 6 nauczycielach), ponad 300 dzieci - siedmioklasowa (o 7 lub, w razie istnienia oddziałów równoległych, o większej liczbie nauczycieli. Ustawa z dnia 17 lutego 1922 roku o zakładaniu i utrzymywaniu publicznych szkół powszechnych, Dziennik Ustaw, nr 18, poz. 143, s. 284.

${ }^{41}$ APP OK, ISK, SPB, sygn. 158, Szkoła w Brdowie. Organizacja.

${ }^{42}$ APP OK, ISK, SPB, sygn. 158, Szkoła w Brdowie. Plan lekcyjny na rok szkolny 1924/1925 klasa II.

${ }^{43}$ APP OK, ISK, SPB, sygn. 158, Szkoła w Brdowie. Siły nauczycielskie.

44 APP OK, ISK, SPB, sygn. 158, Szkoła w Brdowie. Tygodniowy rozkład lekcji i zajęć na rok szkolny 1925/1926. Wykaz personalny grona nauczycielskiego.

${ }^{45}$ APP OK, ISK, SPB, sygn. 158, Szkoła w Brdowie. Organizacja.

${ }^{46}$ APP OK,ISK,SPB, sygn. 158, Szkoła w Brdowie, Siły Nauczycielskie.

47 APP OK,ISK,SPB, sygn. 158, Szkoła w Brdowie. Organizacja.

48 APP OK,ISK,SPB, sygn. 158, Siły nauczycielskie.

49 APP OK,ISK,SPB, sygn. 158, Szkoła w Brdowie. Organizacja.

${ }^{50}$ APP OK,ISK,SPB, sygn. 158, Tygodniowy plan lekcji zajęć na rok 1929/30. Liczba dzieci 1 X. 
Do Brdowa uczęszczały także dzieci z Modzerowa, który nie należał do brdowskiego obwodu $^{51}$.

Publiczna szkoła powszechna, w roku szkolnym 1929/30, składała się z 7 oddziałów, w tym oddziały I-III miały po dwie równoległe klasy ${ }^{52}$. Grono nauczycielskie liczyło siedmioro nauczycieli. Byli to: Jan Galewski - kierownik szkoły oraz Maria Niezgodówna - Petrykowska, Stanisława Bałtruszajtysówna, Józef Opic, Stefan Klotowski, Cecylia Urbańska $^{53}$ oraz ksiądz Józef Markowski, który uczył religii ${ }^{54}$. Wszyscy wymienieni pedagodzy, oprócz księdza Markowskiego, pełnili także funkcje wychowawców klas. Niektórzy mieli pod opieką uczniów kilku klas ${ }^{55}$. Podobnie, jak w poprzednich latach, zatrudniono nowych pedagogów. Byli to wymienieni wyżej: Stanisława Bałtruszajtysówna, Józef Opic ${ }^{56}$ i Stefan Klotowski ${ }^{57}$.

Ciekawy opis stanu organizacyjnego szkoły w Brdowie zawarty jest w zachowanej dokumentacji sprawozdawczej sporządzonej na dzień 1 grudnia 1930 r. Według niego brdowska szkoła posiadała strukturę placówki pięcioklasowej ${ }^{58}$. Dzieci uczyły się w siedmiu oddziałach, z których trzy pierwsze posiadały jeszcze oddziały równoległe. Zgodnie $\mathrm{z}$ istniejącymi wówczas przepisami w szkołach o niższym stopniu organizacyjnym niż siedmioklasowa, wybrane oddziały pobierały naukę w jednej izbie lekcyjnej jako tzw. klasy łączone. W takim zespole jeden oddział miał naukę głośną, a drugi cichą. W brdowskiej szkole wspólną naukę w łączonych oddziałach pobierali uczniowie z oddziałów: IIb z IIIb i VI z VII ${ }^{59}$. Przepisy zakładały istnienie klas jednorocznych i dwurocznych, czyli takich, w których uczniowie pobierali w jednym roku tzw. „naukę głośną”, a w drugim tzw. „naukę cichą”. Taka konstrukcja miała służyć zwiększeniu liczby godzin do

${ }^{51}$ APP OK,ISK,SPB, sygn. 158, Tygodniowy plan lekcji zajęć na rok 1929/30. Liczba dzieci z poszczególnych wsi (miejscowości).

52 APP OK,ISK,SPB, sygn. 158, Tygodniowy rozkład godzin pracy grona nauczycielskiego na rok $1929 / 30$.

${ }_{53}$ Cecylia Urbańska pracowała w Brdowie do 31 lipca 1931 r. Jej miejsce zajęła od 1 września 1931 roku Kazimiera Porażkówna. APP,OK,ISK,SPB, sygn. 158, Siły nauczycielskie.

54 APP OK,ISK,SPB, sygn. 158, Tygodniowy rozkład lekcji zajęć na rok 1929/30. Wykaz personalny grona nauczycielskiego.

55 Jan Galewski - kierownik szkoły - wychowawca klasy III; Maria Niezgodówna - Petrykowska - klasa V; Stanisława Bałtruszajtysówna - klasy I,III,VI; Józef Opic - klasa II; Stefan Klotowski - klasa IV; Cecylia Urbańska - klasy I,II, III. APP OK,ISK,SPB, sygn. 158, Tygodniowy rozkład lekcji zajęć na rok 1929/30. Wykaz personalny grona nauczycielskiego.

56 Józef Opic pracował w Brdowie do emerytury. Od 1946 r. pełnił funkcję kierownika szkoły. Zob. D. Racinowski, Józef Opic (1904-1988) - nauczyciel, wychowawca i społecznik, w: Polonia Maior Orientalis 2016, T. III, s. 181-198.

${ }^{57}$ Stefan Klotowski zatrudniony był na kontrakt od 1.10.1929 do 31.12.1929 r. Od pierwszego stycznia 1930 r. jego miejsce zajął Władysław Kędziora, który już wcześniej pracował w Brdowie. APP OK,ISK,SPB, sygn. 158, Siły nauczycielskie.

$58 \mathrm{~W}$ dokumencie napisano, że szkoła jest czteroklasowa. Cyfra „4” została jednak przekreślona i czerwonym tuszem dopisano, że pięcioklasowa. Na taką strukturę wskazuje też liczba zatrudnionych nauczycieli. APP OK,ISK,SPB, sygn. 158, Wiadomości ogólne (stan z 1 XII 1930), Publiczna szkoła powszechna w Brdowie, k. 259.

${ }^{59}$ APP OK,ISK,SPB, sygn. 158, Organizacja nauki (stan z 1 XII 1930), k. 263. 
nauki niektórych przedmiotów. We wszystkich oddziałach, w sumie w całym cyklu, nauczano jedenastu przedmiotów ${ }^{60}$, z czego najwięcej godzin przeznaczonych było na naukę języka polskiego oraz rachunków i geometrii ${ }^{61}$. Nauczyciele pracujący w brdowskiej szkole uczyli po kilka przedmiotów, a nawet wszystkich w oddziałach I-III. Wszyscy pedagodzy zatrudnieni byli w pełnym wymiarze godzin. Wówczas obowiązywało pensum w wymiarze 30 godzin tygodniowo. Jedynie kierownik szkoły miał mniejsze pensum, wynoszące 18 godzin w tygodniu. Katecheta nauczał religii w wymiarze 12 godzin tygodniowo we wszystkich oddziałach ${ }^{62}$.

Interesująco wyglądają wyniki klasyfikacji uczniów w latach 1928-1931 i 1937. Na koniec roku szkolnego 1928/ 1929 promocji do klasy wyższej nie uzyskało 27\% uczniów zapisanych do szkoły. Najwięcej niepromowanych uczniów było w oddziałach I-III. Z dokumentów wynika, że 41\% uczniów z III oddziału nie uzyskało promocji. Z oddziału II - $40 \%$ uczniów i z oddziału I - $23 \%$ dzieci nie przeszło do wyższego oddziału. Najlepiej było w oddziale VI, ostatnim, gdzie promocję uzyskało 100\% uczniów. W następnym roku szkolnym 1929/1930 nie promowano 26\% uczniów. Podobnie jak w roku poprzednim najwięcej niepromowanych uczniów było w oddziałach I-III. Z tej grupy najmniej promowano uczniów z oddziału II, gdzie 35\% z nich takiej promocji nie uzyskało. Nieco lepiej było w oddziale III, gdzie 30\% uczniów nie przeszło do oddziału programowo wyższego. Najlepiej wypadli uczniowie z oddziału VII, ostatniego. Mogli pochwalić się 100\% klasyfikacją, czyli ukończeniem szkoły w Brdowie ${ }^{63}$. W roku szkolnym 1928/1929 w oddziałach I-III i równoległych zapisanych było 205 uczniów. Z tej grupy ogółem nie promowano 62 uczniów, czyli 31\%. Z wszystkich uczniów niepromowanych w brdowskiej szkole uczniowie $\mathrm{z}$ oddziałów I-III i równoległych stanowili aż 80\%. W następnym roku szkolnym 29\%, czyli 58 na 203 zapisanych, uczniów z tych samych oddziałów nie uzyskało promocji do oddziału programowo wyższego. Stanowili oni $71 \%$ ze wszystkich niepromowanych w szkole ${ }^{64}$. Ze statystyki wynika, że najwięcej uczniów nie promowano w najniższych oddziałach. Można tylko przypuszczać, że nauczyciele uważali, iż uczniowie w tych oddziałach powinni zdobyć pewien zasób wiedzy i umiejętności, które będą niezbędne w dalszej edukacji. Niektórym uczniom potrzeba było więcej czasu, by tę wiedzę oraz umiejętności sobie przyswoić.

Na zakończenie 1931 r. promocję uzyskało 78,5\% uczniów, a 21,5\% jej nie otrzymało. Porównując z poprzednimi latami, widać, że odsetek uczniów bez promocji wyraźnie się zmniejszał. W omawianym czasie najwięcej uczniów bez promocji było w klasie VI,

${ }^{60}$ W Publicznej Szkole Powszechnej w Brdowie nauczano następujących przedmiotów: religia, język polski, rachunki i geometria, rysunki, roboty, śpiew oraz gimnastyka (wszystkie oddziały); język niemiecki (oddziały V-VII); przyroda, geografia a także historia (oddziały III-VII). APP OK,ISK,SPB, sygn. 158, Organizacja nauki (stan z 1 XII 1930), Przedmioty nauki, nr 263.

${ }^{61}$ APP OK,ISK,SPB, sygn. 158, Organizacja nauki (stan z 1 XII 1930), Przedmioty nauki, k. 263.

62 APP OK,ISK,SPB, sygn. 158, Nauczyciele i inni funkcjonariusze szkolni czynni - nieczynni, pobierający uposażenie (stan z 1 XII 1930), k. 264.

${ }^{63}$ APP OK,ISK,SPB, sygn. 158, Wyniki klasyfikacji i ruch uczniów w roku 1929/30, k. 270.

${ }^{64}$ Ibidem. 
bo aż 39\%, a najmniej w klasie I, bo $13 \%$ oraz w II - 20\% ${ }^{65}$. Z biegiem lat wyniki klasyfikacji poprawiały się, ale wciąż liczna dzieci z ocenami niedostatecznymi była znaczna. Aby zmniejszyć odsetek uczniów z ocenami niedostatecznymi Rada Pedagogiczna podjęła w marcu 1937 r. decyzję, aby wszelkimi dostępnymi metodami pomóc uczniom zagrożonym ocenami niedostatecznymi. Postanowiono więc: Wejść bliżej w kontakt z rodzicami tych dzieci, które maja stopnie niedostateczne. Za jeden z najskuteczniejszych środków uznano podciaganie dzieci słabych poza zajęciami lekcyjnymi ${ }^{66}$.

Na koniec roku szkolnego 1936/1937 promowano 83\% uczniów, natomiast 17\% jej nie uzyskało. W porównaniu z poprzednimi latami widoczny jest znaczny spadek w porównaniu z początkiem lat trzydziestych. W liczbie wszystkich niepromowanych uczniów najwięcej ich było z klas III i V - po $20 \%$ oraz I i II - po $18 \%$. Najmniej w klasie VI jeden uczeń oraz klasie VII - dwoje uczniów. Jedna piąta uczniów z klas III i V nie przeszła do wyższego oddziału. Nie było żadnej klasy ze stuprocentową promocją do wyższego oddziału. Nawet w ostatniej, siódmej, klasie dwoje uczniów nie uzyskało promocji, czyli nie ukończyło szkoły w Brdowie ${ }^{67}$.

Nauczyciele brdowskiej szkoły, wystawiając uczniom oceny okresowe lub końcoworoczne, brali pod uwagę następujące dane:

- frekwencję dzieci,

- nieodrabianie lekcji,

- złe warunki domowe,

- brak światła, zeszytów, książek i inne,

- lenistwo u dzieci zdolnych,

- pracowitość dzieci niezdolnych ${ }^{68}$

- trudne warunki pracy przy klasach łączonych ${ }^{69}$.

Dziś te kryteria mogą się wydawać nieco archaiczne i zapewne wzbudziłyby protesty władz oświatowych, nauczycieli, uczniów, rodziców, ale nie sposób odmówić im logiki oraz zdrowego rozsądku w doborze kryteriów oceniania uczniów w szkole. W/w kryteria oceniania uczniów w brdowskiej szkole były stosowane, pedagodzy bowiem w niej uczący, dobrze znali swoich uczniów oraz ich warunki domowe i sytuację rodzinną.

Dzięki dostępnej dokumentacji można prześledzić pochodzenie uczniów uczęszczających do szkoły w Brdowie w omawianym okresie. Ponad połowę z nich stanowiły dzieci pochodzące $z$ rodzin rolników średnich i gospodarstw małorolnych ${ }^{70}$. Około $20 \%$ stanowiły dzieci rzemieślników, a mniej niż 15\% - dzieci z rodzin urzędników państwowych i samorządowych. Do szkoły uczęszczały także dzieci, których rodzice byli robotnikami,

${ }^{65}$ APP OK,ISK,SPB, sygn. 158, Sprawozdanie roczne za rok szkolny 1930/31, k. 250.

${ }^{66}$ APP OK,ISK,SPB, sygn. 158, Protokół z posiedzenia... odbytego w dniu 22.03.1937 r., k. 68.

${ }^{67}$ APP OK,ISK,SPB, sygn. 158, Protokół z posiedzenia... odbytego w dniu 12.06.1937 r., k. 58.

${ }^{68}$ APP OK,ISK,SPB, sygn. 158, Protokół z posiedzenia... odbytego w dniu 12.12.1936 r., k. 104.

${ }^{69}$ APP OK,ISK,SPB, sygn. 158, Protokół z posiedzenia... odbytego w dniu 22.03.1937 r., k. 68.

${ }^{70}$ Do grupy rolników średnich zaliczono tych, których gospodarstwa liczyły od 5 do 50 ha. Gospodarstwa małorolne to te poniżej 5 ha. APP OK,ISK,SPB, sygn. 158, Zawód i stanowisko w zawodzie rodziców uczniów, k. 267. 
kupcami, urzędnikami państwowymi oraz samorządowymi a także wyrobnikami, czyli osobami wynajmującymi się do różnych prac fizycznych ${ }^{71}$. Najmniejszą grupę stanowili uczniowie z rodzin nauczycielskich oraz sklasyfikowanych jako służba i niżsi funkcjonariusze państwowi ${ }^{72}$. Być może taka struktura zawodowa rodziców uczniów uczęszczających do brdowskiej szkoły była jednym z powodów tak znacznej liczby uczniów, którzy nie otrzymywali promocji do oddziału wyższego. Dzieci z rodzin rolniczych były często wykorzystywane do pomocy przy drobniejszych pracach w gospodarstwie. Opuszczały przez to więcej zajęć. Działo się tak szczególnie w okresie wiosennym - siew zbóż, sadzenie ziemniaków, buraków i jesiennym - wykopki. Rodzice nie mieli czasu, by dopilnować realizację obowiązku szkolnego swoich dzieci. Wielu rodziców było analfabetami, co wykluczało jakąkolwiek pomóc dzieciom. Ważniejsze wydawały się dodatkowe i darmowe ręce do pracy niż najmowanie wyrobników, którym trzeba było płacić. Można stwierdzić, że obowiązki w gospodarstwie, wynikające w dużej mierze z ubóstwa, były jedną z przyczyn wysokiej absencji dzieci w szkole pochodzących z rodzin rolniczych lub tych zatrudniających się u innych.

Janusz Jędrzejewicz, minister Wyznań Religijnych i Oświecenia Publicznego, opracował i wcielił w życie nowy ustrój szkolnictwa w Polsce międzywojennej. Ustawa z dnia 11 marca 1932 r. o ustroju szkolnictwa ${ }^{73}$ wprowadziła reformę, zwaną od jej twórcy, „Jędrzejewiczowską”, która uporządkowała i ujednoliciła szkolnictwo na poziomie podstawowym i ponadpodstawowym. Wcześniejsze akty prawne regulujące system szkolnictwa służyły raczej dostosowaniu odmiennych sieci szkół odziedziczonych po trzech zaborcach. Nowy akt prawny wprowadził trzy stopnie organizacyjne dla szkół powszechnych (podstawowych). Od tej pory istniały szkoły powszechne I, II i III stopnia $^{74}$, przy czym szkoła III stopnia była stopniem najwyższym, realizującym wszystkie trzy szczeble programowe: Szkoty stopnia pierwszego wypetniaja catkowicie pierwszy ${ }^{75}$ szczebel programowy, a nadto najważniejsze składniki szczebla II-go i III-go. Szkoła pierwszego stopnia ma cztery klasy, z których I i II sa jednoroczne, III - dwuletnia, IV - trzyletnia. [...] Szkoły stopnia drugiego wypetniaja catkowicie pierwszy $i$ drugi szczebel programowy oraz najistotniejsze składniki szczebla III. Szkoła stopnia drugiego ma 6 klas, z których 5 pierwszych jest jednorocznych, VI zaś dwuletnia. [...] Szkoła [...] trzeciego stopnia, wykonywa wszystkie trzy szczeble programowe $w$ petnym zakresie,

${ }^{71}$ Stownik języka polskiego PWN, t. III, Warszawa 1981, s. 840.

72 APP OK,ISK,SPB, sygn. 158, Zawód i stanowisko w zawodzie rodziców uczniów, k. 267.

73 Ustawa z dnia 11 marca 1932 roku o ustroju szkolnictwa, Dz. U., 1932, nr 38, Poz. 389, s. 639-645, [dostęp 2.01.2015] http://isap.sejm.gov.pl/DetailsServlet?id=WDU19320380389.

${ }^{74}$ Ustawa z dnia 11 marca 1932 roku o ustroju szkolnictwa, art. 12, Dz. U., 1932, nr 38, Poz. 389, s. 640, http://isap.sejm.gov.pl/DetailsServlet?id=WDU19320380389 [dostęp 2.01.2015].

75 Według art. 11 ustawy o ustroju szkolnictwa: W programie szkoły powszechnej rozróżnia się trzy szczeble: szczebel pierwszy obejmuje elementarny zarys wykształcenia ogólnego, szczebel drugi jest rozszerzeniem i pogłębieniem szczebla pierwszego, szczebel trzeci ma nadto przysposobić młodzież pod względem spoteczno-obywatelskim i gospodarczym, w: Program nauki w publicznych szkołach powszechnych stopnia trzeciego z polskim językiem nauczania, Biblioteka Oświaty i Wychowania, t. 1, Lwów [1934?], s. X. 
pierwszy w ciagu 4 pierwszych lat nauki, drugi w ciagu 2 lat następnych, trzeci w ciagu ostatniego roku nauki. [...] Szkoła stopnia III ma 7 klas jednorocznych ${ }^{76}$.

Kurator Okręgu Szkolnego Warszawskiego - Wiktor Ambroziewicz - dnia 17 lutego 1937 r. wydał orzeczenie w sprawie organizacji szkoły w Brdowie. Powołując się m.in. na plan sieci szkolnej opracowany przez gminę Lubotyń oraz protokół posiedzenia Dozoru Szkolnego gminy Lubotyń z dnia 20 października 1936 roku, postanowił: $W$ Brdowie gm. Lubotyń w pow. Kolskim organizuje się siedmioklasowa publiczna szkoła powszechna, do której obwodu włączone zostaną: wieś Brdów, Kolonia Brdowskie Nowiny, wieś Bugaj, wieś parcele Psary oraz Kolonia Ostrowy ${ }^{77}$.

Na podstawie orzeczenia Kuratora Inspektor Szkolny w Koninie z dniem 15 listopada 1937 r. przemianował pięcioklasową Publiczną Szkołę Powszechną w Brdowie na Publiczną Szkołę Powszechną stopnia III ${ }^{78}$, czyli z siedmioma klasami jednorocznymi. Był to ostatni etap rozwoju brdowskiej szkoły w okresie międzywojennym. Zaledwie dwa roczniki absolwentów zdołały opuścić mury szkoły w Brdowie po reorganizacji. Jej dalszą działalność przerwał wybuch II wojny światowej i hitlerowska okupacja.

W Publicznej Szkole Powszechnej III stopnia w Brdowie, w całym cyklu nauczano ogółem 11 przedmiotów ${ }^{79}$, z czego siedem przez cały siedmioletni cykl. Wśród nich były wszystkie przedmioty artystyczne - rysunek, śpiew i zajęcia praktyczne. Najwięcej godzin przeznaczonych było na naukę języka polskiego i arytmetyki z geometrią. Wybrani uczniowie z klas V-VII raz w tygodniu mieli godzinne zajęcia w ramach prowadzonego w szkole chóru ${ }^{80}$. Ciekawostką może być fakt, iż w tym czasie nie nauczano żadnego języka obcego, tym bardziej że w latach wcześniejszych uczono języka niemieckiego.

W zreorganizowanej szkole pracowało pięcioro nauczycieli, w tym czworo zatrudnionych na stałe $\mathrm{i}$ jeden na kontrakt ${ }^{81}$ oraz katecheta zatrudniony na godziny ${ }^{82}$.

Ze względu na dużą liczbę dzieci w roku szkolnym 1937/1938 zorganizowano dwa równolegle pierwsze oddziały, w których łącznie uczyło się 75 uczniów. Szczupłość kadry spowodowała, że nauczyciele musieli pełnić funkcję wychowawcy w dwóch oddzia-

${ }^{76}$ Program nauki w publicznych szkołach powszechnych drugiego stopnia z polskim językiem nauczania, Lwów 1936, s. XI.

77 APP OK,ISK,SPB, sygn. 158, Orzeczenie w sprawie..., k. 83.

${ }^{78}$ APP OK,ISK,SPB, sygn. 158, Pismo Inspektora Szkolnego w Koninie z dnia 10 listopada 1937 roku, k. 40 .

79 W roku szkolnym 1937/1938 i następnym nauczano w Brdowie następujących przedmiotów: religia, język polski, historia, geografia, nauki przyrodnicze, arytmetyka z geometrią, rysunek, zajęcia praktyczne, śpiew, ćwiczenia cielesne ( wychowanie fizyczne) oraz chór. APP OK,ISK,SPB, sygn. 158, Sprawozdanie z organizacji... z dnia 2.10.1937.

80 Ibidem.

${ }^{81}$ W roku szkolnym 1937/1938 w brdowskiej szkole pracowali: Marian Janowski - kierownik, Walentyna Janowska, Stanisława Kędziorowa, Józef Opic, Stanisława Stuglikowa - kontrakt oraz nauczyciel religii. APP OK,ISK,SPB, sygn. 158, Sprawozdanie z organizacji... z dnia 2.10.1937, Grono nauczycielskie i podział zajęć.

${ }^{82}$ APP OK,ISK,SPB, sygn. 158, Sprawozdanie z organizacji... z dnia 2.10.1937, Grono nauczycielskie i podział godzin. 
łach (klasach) jednocześnie ${ }^{83}$, co wydaje się dziś zadaniem nader trudnym, wręcz niemożliwym. Trzeba wziąć pod uwagę także liczbę dzieci w poszczególnych klasach, która znacznie odbiegała od dzisiejszych standardów ${ }^{84}$. Wychowawcy pracujący w tym czasie musieli zapewne włożyć wiele trudu, by opanować zespoły klasowe i wychować uczniów zgodnie z przyjętymi wówczas założeniami oraz oczekiwaniami władz oświatowych. Jak wynika $\mathrm{z}$ dalszej analizy dokumentów efekty pracy wychowawców były co najmniej dobre.

Intersująco wygląda również tygodniowy plan lekcji dla uczniów w roku szkolnym 1937/1938. Uczniowie klas Ib i II uczęszczali na zajęcia na tzw. drugą zmianę, czyli po zakończeniu zajęć przez uczniów klas, którzy rozpoczynali zajęcia od rana ${ }^{85}$. Ostatnie zajęcia uczniów z tzw. drugiej zmiany kończyły się jednak już o godzinie 14.25. Nie jest to zbyt późna godzina przy dzisiejszych standardach w polskiej oświacie. Nauka na „drugą zmianę" spowodowana była niewystarczającą liczbą izb lekcyjnych w brdowskiej szkole. Brakowało pomieszczeń, by jednocześnie od rana prowadzić zajęcia we wszystkich klasach.

Tygodniowy rozkład liczby godzin zajęć edukacyjnych w poszczególnych klasach był zróżnicowany. Im była ona programowo wyższa, tym zajęć było więcej. Pamiętać też należy, że tydzień pracy liczył 6 dni - uczniowie uczyli się od poniedziałku do soboty włącznie. Rozkład godzin zajęć edukacyjnych w poszczególnych klasach ilustruje tabelka. Dla porównania podano także tygodniowy wymiar godzin obowiązkowych zajęć edukacyjnych uczniów w roku szkolnym 2014/2015 z uwzględnieniem zajęć dodatkowych z puli zajęć do dyspozycji dyrektora szkoły realizowanych w Zespole Szkół w Brdowie, a także liczbę zajęć w klasach w ramach reformy oświaty.

Wyraźną różnicę w liczbie godzin widać w klasach I i II. Najmłodsi uczniowie przebywali w szkole dziennie średnio 2,5 godziny lekcyjnej, a uczniowie klasy II średnio 3 godziny. Uczniowie klasy IV uczyli się średnio 4 godziny dziennie, a uczniowie klas V i VI mieli dziennie ponad 5 godzin lekcyjnych. Porównując te liczby z godzinami w roku szkolnym 2014/2015, widać, że najwięcej godzin przybyło uczniom klas I i II oraz IV. Średnie liczby godzin nauki obecnie są też większe ze względu na pięciodniowy tydzień pracy. Uczniowie klas I i II uczą się codziennie średnio ponad 4 godziny lekcyjne. Uczniowie klas VI i I gim. mają średnio po 6 i więcej godzin lekcyjnych dziennie. Przyrost zajęć edukacyjnych w tygodniu jest znaczny. Wynika to też ze znacznie większej liczby nauczanych przedmiotów. O ile uczeń klasy VII w roku szkolnym 1937/1938 uczył się 10 przedmiotów, to uczeń I klasy gim. [dawna klasa VII] w roku szkolnym

${ }^{83}$ Wychowawcy klas w roku szkolnym 1937/1938: Marian Janowski - kierownik - klasy VI i VII; Walentyna Janowska - klasy Ib i III; Stanisława Kędziorowa - klasy 1a i V; Józef Opic - klasa II; Stanisława Stuglikowa - na kontrakcie - klasa IV. APP OK,ISK,SPB, sygn. 158, Sprawozdanie z organizacji... z dnia 2.10.1937, Grono nauczycielskie i podział godzin.

${ }^{84}$ Liczba uczniów zapisanych do poszczególnych klas w roku szkolnym 1937/1938: Ia - 37; Ib - 38; II -60; III - 55; IV - 60; V - 58; VI - 34; VII - 19. APP OK,ISK,SPB, sygn. 158, Sprawozdanie z organizacji... z dnia 2.10.1937, Uczniowie według stanu z dnia 1 X 1937 r.

${ }^{85}$ APP OK,ISK,SPB, sygn. 158, Rozkład lekcji w publicznej szkole powszechnej w Brdowie na rok szkolny $1937 / 1938$, k. 35. 
Tabela 1. Liczba godzin zajęć edukacyjnych uczniów w tygodniu realizowanych w brdowskiej szkole w trzech wybranych latach

\begin{tabular}{|c|c|c|c|}
\hline \multirow[b]{2}{*}{ Klasa } & \multicolumn{3}{|c|}{ Liczba godzin lekcyjnych uczniów w tygodniu } \\
\hline & rok szkolny $1937 / 1938^{86}$ & rok szkolny $2014 / 2015^{87}$ & $\begin{array}{l}\text { rok szkolny } 2017 / 2018^{88} \\
\text { początek reformy, likwidacja } \\
\text { gimnazjów }\end{array}$ \\
\hline I & 15 & 22 & 23 \\
\hline II & 18 & 23 & 22 \\
\hline III & 22 & 23 & 23 \\
\hline IV & 24 & 29 & 29 \\
\hline $\mathrm{V}$ & 28 & 29 & 31 \\
\hline VI & 32 & 31 & 33 \\
\hline VII & 31 & 32 [I gim.] & 35 \\
\hline
\end{tabular}

2014/2015 miał zajęcia z 15 przedmiotów. Uczniowie VII klasy będą uczyć się 14 przedmiotów $^{89}$. Uczniowie tej klasy, jak wynika z tabeli, będą mieć najwięcej zajęć edukacyjnych w tygodniu, bo aż 35 godzin, co stanowi 7 godzin dziennie ${ }^{90}$.

Dla uzyskania pełniejszego obrazu pracy uczniów i pedagogów warto prześledzić rozkład ocen niedostatecznych z poszczególnych przedmiotów we wszystkich klasach. Dane dotyczą klasyfikacji końcoworocznej z 12 czerwca 1937 r.

Najwięcej ocen niedostatecznych uzyskali uczniowie z języka polskiego i arytmetyki $\mathrm{z}$ geometrią, to $72 \% \mathrm{z}$ wszystkich ocen niedostatecznych wystawionych $\mathrm{w}$ omawianym roku szkolnym. Uczniowie klasy $\mathrm{V}$ uzyskali najwięcej niedostatecznych not, co stanowi $34 \%$ z wszystkich wystawionych. Jak wynika z tabelki, była to klasa najsłabsza, uczniowie bowiem uzyskali oceny niedostateczne aż z 7 przedmiotów, w tym z takich, jak rysunek i zajęcia praktyczne. Wiele ocen niedostatecznych uzyskali także uczniowie najmłodszych klas I i II. Najlepiej wypadli uczniowie klasy VII i VI, bo tylko po 4 oceny niedostateczne. W omawianym roku szkolnym na 292 uczniów uczęszczających do brdowskiej szkoły prawie 47\% z nich otrzymało co najmniej jedną ocenę niedostateczną na zakończenie roku szkolnego 1936/1937.

${ }^{86}$ APP OK,ISK,SPB, sygn. 158, Rozkład lekcji w publicznej szkole powszechnej w Brdowie na rok szkolny $1937 / 1938$, k. 35.

${ }^{87}$ Tygodniowy rozkład zajęć w Zespole Szkół w Brdowie obowiązujący od 1.09.2014 r.

${ }_{88}$ Rozporządzenie Ministra Edukacji Narodowej z dnia 28 marca 1917 roku w sprawie ramowych planów nauczania dla szkół publicznych. Załącznik 1, Dz. U. RP 2017, poz. 703, s. 7-8.; Tygodniowy rozkład zajęć w Szkole Podstawowej w Brdowie obowiązujący od 1.09.2017 r.

${ }^{89}$ Ibidem, s. 7-7.

${ }^{90}$ Do tygodniowego rozkładu zajęć w Szkole Podstawowej w Brdowie nie wliczono zajęć rewalidacyjnych przeznaczonych dla uczniów ze specjalnymi potrzebami edukacyjnymi. 
Tabela 2. Oceny niedostateczne z poszczególnych przedmiotów uzyskane przez uczniów brdowskiej szkoły na zakończenie roku szkolnego 1936/1937

\begin{tabular}{|c|c|c|c|c|c|c|c|c|c|}
\hline \multirow[b]{2}{*}{ 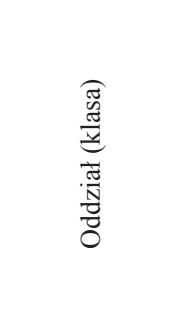 } & \multirow[b]{2}{*}{ 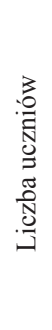 } & \multicolumn{7}{|c|}{ Oceny niedostateczne z poszczególnych przedmiotów ${ }^{91}$} & \multirow{2}{*}{ 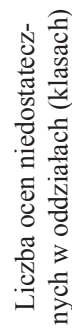 } \\
\hline & & 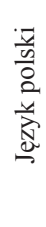 & 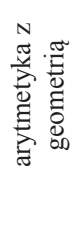 & 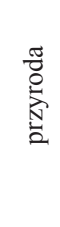 & 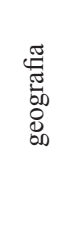 & 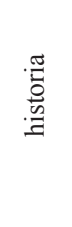 & 范 & 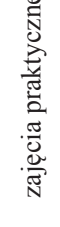 & \\
\hline I & 57 & 9 & 9 & - & - & - & - & - & 18 \\
\hline II & 44 & 9 & 9 & - & - & - & - & - & 18 \\
\hline III & 51 & 10 & 10 & - & - & - & - & - & 20 \\
\hline IV & 49 & 9 & 9 & 6 & 1 & - & - & 2 & 27 \\
\hline $\mathrm{V}$ & 50 & 11 & 10 & 3 & 11 & 6 & 2 & 3 & 46 \\
\hline VI & 17 & 1 & 1 & - & 1 & - & 1 & - & 4 \\
\hline VII & 24 & 1 & 1 & 2 & - & - & - & - & 4 \\
\hline $\begin{array}{l}\text { Razem oceny } \\
\text { niedostateczne } \\
\text { z przedmiotów }\end{array}$ & 292 & 50 & 49 & 11 & 13 & 6 & 3 & 5 & 137 \\
\hline $\begin{array}{c}\% \text { udział ocen } \\
\text { niedostatecz- } \\
\text { nych }\end{array}$ & 100 & 17 & 17 & 0,04 & 0,04 & 0,02 & 0,01 & 0,02 & 46,9 \\
\hline
\end{tabular}

Pewne światło na poziom nauczania w brdowskiej szkole w okresie międzywojennym rzucają również sprawozdania i protokoły z wizytacji przeprowadzonych przez władze oświatowe w latach 1935-1939. Sprawozdanie powizytacyjne z kontroli przeprowadzonej 5 grudnia 1935 r. zawiera krótką charakterystykę obserwowanych klas i pracy nauczycieli. Warto przytoczyć w całości ocenę dzieci w hospitowanych klasach. Kontrolujący napisali:

Kl. I - dzieci dość urobione i rozgarnięte, czytaja, pisza i rachuja zadawalajaco. Zeszyty utrzymane czysto, porzadnie.

Kl. IV - Dzieci mało urobione i opanowane. Znajomość ortografii niedostateczna, wiadomości z gramatyki słabe. Metody pracy niezbyt właściwe.

Kl. V-Dzieci żywe, dość rozgarnięte, posiadaja wiadomości zadawalające. $W$ rachunkach mają trudności w rozwiązywaniu samodzielnie zadań.

Kl. VII - Dzieci za mało wdrożone do samodzielnej pracy. Wiadomości z geografii i nauki o Polsce posiadaja werbalne ${ }^{92}$.

91 APP OK,ISK,SPB, sygn. 158, Protokół z posiedzenia Rady Pedagogicznej... z dnia 12.06.1937 roku, k. 58.

92 APP OK,ISK,SPB, sygn. 158, Sprawozdanie powizytacyjne z dnia 5.12.1935, k. 1. 
Obserwowane klasy wypadły dość dobrze, wyłączając klasę IV, która została negatywnie oceniona. We wnioskach podsumowujących wizytację napisano, że poziom ortografii w szkole wymaga poprawy. Wskazano też na duże braki dotyczące higieny w szkole oraz kultury życia codziennego wśród uczniów. Dokonano również oceny pracy kadry nauczycielskiej. Stwierdzono: Stosunek nauczycieli do dzieci mity, atmosfera pracy w poszczególnych klasach sympatyczna, lecz atmosfera $w$ gronie nauczycielskim niedobra [...] zadrażnienia $i$ wzajemne animozje $e^{93}$.

Wizytatorzy, kończąc sprawozdanie, zaproponowali rekomendacje, które miały wzmocnić słabe strony szkoły oraz pracy nauczycieli. Wskazano na następujące obszary: Należy uzdrowić atmosfere pracy $w$ gronie nauczycielskim, usunać braki $w$ zakresie kultury życia codziennego, więcej troski wkładać w przestrzeganie zasad higieny w szkole, poprawić wyniki $w$ zakresie nauczania ortografii, $w$ metodach pracy więcej zwracać uwagi na zasadę samodzielnej pracy dzieci $i^{94}$.

Kolejna wizytacja odbyła się w dniach 26-27 stycznia 1938 r., wkrótce po reorganizacji struktury szkoły. Wizytowano klasy: II, IV-VII. Badano wyniki nauczania w klasach: I-II i VII. Stefan Ubysz - podinspektor szkolny - napisał w sprawozdaniu: Stan wychowawczy i poziom naukowy szkoły na ogół dostateczny. Dzieci dość rozgarnięte, jednak $w \mathrm{kl}$. II-IV mało opanowane. Sa to klasy liczne i praca wychowawcza nastręcza w nich duże trudności $i^{95}$.

W rekomendacjach do dalszej pracy napisano, że należy zwrócić większą uwagę na czystość w izbach lekcyjnych i wśród uczniów, zadbać o okrycia wierzchnie uczniów, zadbać o punktualne przychodzenie uczniów na zajęcia oraz poprawić frekwencję. Sporo miejsca poświęcono na wskazanie obszarów, które miały poprawić poziom nauczania w szkole. Wizytujący zaproponował do dalszej pracy:

- stosowanie samodzielnej pracy dzieci,

- zwiększenie aktywności dzieci w czasie prowadzenia lekcji,

- wdrażanie do umiejętnego korzystania z podręczników,

- przydzielanie konkretnych, możliwych do wykonania i skontrolowania zadań domowych celowo i planowo,

- poprawić wyniki nauczania w zakresie ortografii ${ }^{96}$.

Podinspektor odniósł się także do pracy pedagogów. Napisał, że grono nauczycielskie nie stanowi zharmonizowanej jednolitej osobowości grupowej ${ }^{97}$. Podał pedagogom wytyczne do dodatkowej pracy. Napisał: Podjać na terenie rady Pedagogicznej prace samo-

\footnotetext{
${ }^{93}$ APP OK,ISK,SPB, sygn. 158, Sprawozdanie powizytacyjne z dnia 5.12.1935, k. 2.

94 Ibidem.

${ }^{5}$ APP OK,ISK,SPB, sygn. 158, Sprawozdanie z wizytacji publicznej szkoły powszechnej III-go stopnia w Brdowie, k. 5.

96 Ibidem.

97 APP OK,ISK,SPB, sygn. 158, Sprawozdanie z wizytacji publicznej szkoły powszechnej III-go stopnia w Brdowie, k. 5.
} 
kształceniowa zakresie metodyczno-dydaktycznym $i w$ zakresie stosowania właściwych środków pedagogicznych $w$ wychowywaniu młodzieży ${ }^{98}$.

Po raz drugi z kolei wizytujący zwrócili uwagę na nie najlepszą sytuację w gronie nauczycielskim. Podkreślono też konieczność dokształcania się kadry nauczycielskiej w brdowskiej szkole.

Ostatnia wizytacja, w okresie międzywojennym, miała miejsce w dniach 23-24 marca 1939 r. Badano warunki pracy, warunki i wyniki pracy dydaktyczno-wychowawczej. Kontrola objęła wszystkie klasy i wszystkich pedagogów uczących w brdowskiej szkole. Interesujący jest opis kontrolowanych klas. Podinspektor szkolny Kazimierz Stasierski napisał:

Kl. I-dzieci wystawiaja się, pisza, czytaja dostatecznie.

Kl. II - mówienie i czytanie dość dobre, wyniki w ortografii i arytmetyce dostatecz-

ne. Pismo staranne.

Kl. III - wyniki w języku polskim-mówienie, pisanie, czytanie dostateczne - w gramatyce bardzo słabe. Wiadomości z arytmetyki - tabliczka mnożenia, dodawanie,

odejmowanie - dostateczne.

Kl. IV - wyniki z arytmetyki dostateczne.

Kl. V-czytanie i ortografia u dzieci dostateczne. Wiadomości z gramatyki dobre.

Lekcję z arytmetyki ujęto dostatecznie. [...] Ogółem wyniki z arytmetyki słabe.

Wiadomości z przyrody [...] dostatecznie utrwalone.

Kl. VI - Lekcje z geografii i historii przeprowadzono interesujaco. Wyniki z geografii [...] dostateczne. Wyniki z historii [...] na ogót dobre ${ }^{99}$.

Wskazano na dobry poziom wychowawczy dzieci przejawiający się m.in. w tym, że dzieci były grzeczne, uprzejme oraz „na ogół czyste”. Dbały też o estetykę zeszytów. Zaznaczono po raz kolejny, iż grono nie tworzy jeszcze zwartej całości, co jest konieczne do kontynuowania należytej pracy ${ }^{100}$. W zaleceniach pokontrolnych podinspektor szkolny napisał m.in.:

- uwzględnić więcej aktywności dzieci; ograniczać drobne pytania, a stosować więcej zagadnień; pamiętać o wycieczkach.

- dążyć do zmniejszenia liczby drugorocznych przez zaopiekowanie się szczególnie uczniami słabszymi, a przy ustalaniu liczby drugorocznych uwzględniać $w$ dużej mierze warunki domowe ucznia i stosować bezwzględny obiektywizm ${ }^{101}$.

Wizytator zwrócił szczególną uwagę na problem „repetentów” (uczniów powtarzających klasę). Uznał bowiem, że jest ich zbyt dużo. Przeprowadzona wśród tych uczniów ankieta wskazała, jak się wydaje, na przyczyny ich pozostania w tej samej klasie na kolejny rok. W konkluzji sprawozdania wskazał więc sposoby rozwiązania tego problemu

98 Ibidem.

99 APP OK,ISK,SPB, sygn. 158, Sprawozdanie z wizytacji publicznej szkoły powszechnej III-go stopnia W Brdowie, k. 7-8.

100 APP OK,ISK,SPB, sygn. 158, Sprawozdanie z wizytacji publicznej szkoły powszechnej III-go stopnia w Brdowie, k. 7.

101 APP OK,ISK,SPB, sygn. 158, Sprawozdanie z wizytacji publicznej szkoły powszechnej III-go stopnia w Brdowie, k. 8 . 
i pośrednio zawarł przyczyny nadmiernej liczby „repetentów” w brdowskiej szkole. Nie wiadomo, czy zalecenia zostały wdrożone i przyniosły pozytywne efekty, bowiem kilka miesięcy później wybuchła II wojna światowa i szkoła została zamknięta na ponad pięć lat. Ostatnia wizytacja odbyła się już w nowym budynku szkoły, więc zalecenia z poprzednich kontroli w tym zakresie zostały zrealizowane. Znacznie poprawiły się warunki pracy i nauczania. Przeprowadzka do nowego budynku szkoły miała też wpływ na poprawę higieny i kultury osobistej wśród uczniów, na co wskazał wizytujący placówkę. Wizytatorzy dostrzegali sukcesy, ale i słabe strony pracy nauczycieli. Widzieli warunki ich pracy i trudności wychowawcze. Doceniali pracę społeczną pedagogów, a zwłaszcza drużyny harcerskiej, która, jak napisano największą żywotność okazuje $e^{102}$.

Szkoła w Brdowie, posiadająca bardzo długą tradycję, bo sięgającą połowy XV w., rozwinęła się w pełni dopiero w okresie międzywojennym. Ze szkoły jednoklasowej z zatrudnionym jednym nauczycielem w 1918 r., przerodziła się w szkołę siedmioklasową, z pełną osadą kadrową, w przededniu wybuchu II wojny światowej. Po wielu latach starań i działań wybudowano nowy piękny budynek szkoły, który był zaledwie pierwszym etapem planowanego kompleksu szkolnego. Uczniowie i nauczyciele mieli okazję uczyć się i pracować w nowym budynku przez jeden rok. Znacznie polepszyły się warunki lokalowe oraz warunki pracy, a także nauki. Mimo bardzo trudnych warunków pracy, jakie panowały prawie przez cały okres międzywojenny, pedagodzy osiągali zadowalające wyniki nauczania i wychowania uczniów uczęszczających do szkoły w Brdowie. Z perspektywy obecnego nauczyciela warunki pracy w szkole w latach 1919-1939 były skrajnie trudne. Trudno sobie dziś wyobrazić, mimo wielu bolączek i trudności, jakie obecne są w dzisiejszej szkole, klasy liczących po 40 i więcej uczniów gnieżdżących się w małej salce bez wsparcia współczesnych środków przekazu i komunikacji. Można pokusić się o stwierdzenie, że okres międzywojenny był dla brdowskiej szkoły czasem budowy, kształtowania i krzepnięcia. Wybuch II wojny światowej zniweczył cały dorobek, pracę i trud włożony w kształtowanie szkoły w Brdowie.

\section{Bibliografia}

\section{Źródła}

Archiwum Główne Akt Dawnych w Warszawie

Inwentarz Szkoły Elementarnej w m. Brdowie wg stanu z 1824 r. i 1830 r.

Archiwum Państwowe w Poznaniu. Oddział w Koninie

Inspektorat Szkolny w Kole. Szkoła Powszechna w Brdowie: organizacja, historia, akta obrazujące działalność 1924-1939.

Archiwum Szkoły Podstawowej w Brdowie

Kronika szkolna 1936-1939.

Kodeks Dyplomatyczny Wielkopolski, t. 1, Poznań 1877.

Monumenta Historica Dioeceseos Wladislaviensis (1903), T.22, s. 125.

102 Ibidem. 
Dekret o obowiązku szkolnym z dnia 7 lutego 1919 roku, (Dziennik Prawny 1919, nr 14, poz. 147) Ustawa z dnia 17 lutego 1922 roku o zakładaniu i utrzymywaniu publicznych szkół powszechnych, (Dz. U. 1922, nr 18, poz. 143)

Ustawa z dnia 11 marca 1932 roku o ustroju szkolnictwa, (Dz. U. 1932, nr 38, Poz. 389)

Program nauki w publicznych szkołach powszechnych stopnia trzeciego z polskim językiem nauczania, Biblioteka Oświaty i Wychowania, t. 1, Lwów [1934?], s. X.

Program nauki w publicznych szkołach powszechnych drugiego stopnia z polskim językiem nauczania, Lwów 1936, s. XI.

Tygodniowy rozkład zajęć w Zespole Szkół w Brdowie obowiązujący od 1.09.2014 r.

Rozporządzenie Ministra Edukacji Narodowej z dnia 28 marca 1917 roku w sprawie ramowych planów nauczania dla szkół publicznych. Załącznik 1, (Dz. U. RP 2017, poz. 703).

Tygodniowy rozkład zajęć w Szkole Podstawowej w Brdowie obowiązujący od 1.09.2017 r.

\section{Opracowania}

Mozga J. Dzieje konwentu Paulinów w Brdowie, „Studia Claromontana” 1984, nr 5.

Stownik języka polskiego PWN, t. III, Warszawa 1981, s. 840.

Mujta J.S., Gmina Babiak przeszłość i teraźniejszość, Babiak 1995.

Racinowski D., Józef Opic (1904-1988) - nauczyciel, wychowawca i społecznik, Polonia Maior Orientalis, T. III, 2016.

Rozwadowski J., Bulla z r. 1136 jako najstarszy zabytek języka polskiego, Kraków 1909.

Wiesiołowski J., Fundacje paulińskie XIV i XV wieku nas tle ruchu fundacyjnego klasztorów w Polsce, „Studia Claromontana” 1985, nr 6, s. 151.

Zbudniewek J., Dzieje osady brdowskiej, „Roczniki Teologiczno-Kanoniczne” 1984, t. XXXI, z. 4.

Zbudniewek J., Paulini wczoraj i dzisiaj, „Studia Claromontana” 2007, nr 25.

Strony internetowe

http://isap.sejm.gov.pl/DetailsServlet?id=WDU19190140147 